\title{
The increase in absolute theta power and the inhibition of light stimulus in
}

\section{cybersickness}

\section{O aumento do poder theta absoluto e a inibição do estímulo da luz no cybersickness \\ El aumento del poder theta absoluto y la inhibición del estímulo luminoso en el cibersikness}

Flávia Freitas

ORCID: https://orcid.org/0000-0002-8706-6621

Universidade Federal do Delta do Parnaíba, Brazil E-mail: flaviasabrynne@ hotmail.com

Kelma Galeno

ORCID: https://orcid.org/0000-0003-1925-7079

Universidade Federal do Delta do Parnaíba, Brazil E-mail: kelmagaleno@yahoo.com.br

Juliana Bittencourt

ORCID: https://orcid.org/0000-0003-1959-6345

Universidade Federal do Delta do Parnaíba, Brazil

E-mail: juju_bitt@yahoo.com.br

Francisco Magalhães

ORCID: https://orcid.org/0000-0002-8542-4245

Universidade Federal do Delta do Parnaíba, Brazil E-mail: fisiofranciscoxavier@gmail.com

Valécia Natália Carvalho da Silva

ORCID: https://orcid.org/0000-0001-5739-0722

Universidade Federal do Delta do Parnaíba, Brazil

E-mail: valeciacs@gmail.com

Thayaná Ribeiro Silva Fernandes

ORCID: https://orcid.org/0000-0002-6590-4620

Universidade Federal do Delta do Parnaíba, Brazil

E-mail: thayana.fernandes@hotmail.com

Antonio Thomaz de Oliveira

ORCID: https://orcid.org/0000-0003-0277-6833

Universidade Federal do Delta do Parnaíba, Brazil

E-mail: thomaz159@gmail.com

Jacks Renan Neves Fernandes

ORCID: https://orcid.org/0000-0001-7868-0673

Universidade Federal do Delta do Parnaíba, Brazil

E-mail: jacks.renan@ifpi.edu.br

Valéria de Fátima Veras de Castro

ORCID: https://orcid.org/0000-0001-8281-3029

Universidade Federal do Delta do Parnaíba, Brazil E-mail: castrovaleria701@gmail.com

Victor Hugo do Vale Bastos

ORCID: https://orcid.org/0000-0001-7425-4730

Universidade Federal do Delta do Parnaíba, Brazil

E-mail: victorhugobastos@ufpi.edu.br

Silmar Silva Teixeira

ORCID: https://orcid.org/0000-0002-9240-1228

Universidade Federal do Delta do Parnaíba, Brazil E-mail: silmateixeira@ufpi.edu.br

\begin{abstract}
Cybersickness results from the visual vestibule conflict, that is, the incoherence between the sensations related to real movement, in the virtual environment, and the visual stimuli. In response to the virtual environment, one can observe discomforts such as nausea, difficulty in concentrating, and headaches, among others. There are no studies in the literature that analyze the inhibition control of light stimuli in individuals sensitive to Cybersickness. Therefore, this study looked at the control of light stimulus inhibition in Cybersickness. The Sickness Susceptibility Questionnaire was used to divide the subjects into experimental and control groups, and quantify the signs and symptoms, comparing them before and after 3D virtual immersion and. Participants in both groups were examined with EEGq for absolute theta band power in the dorsolateral prefrontal cortex and ventrolateral prefrontal cortex during the light stimulus inhibition task before and after participants watched the 3D video. The partial results showed that there was an increase in the
\end{abstract}


absolute theta band power in both groups comparing the moments before and after, as well as a significant difference in the experimental group compared to the control, for the same moment. Thus, it was observed that individuals who were exposed to 3D virtual reality and developed Cybersikness, showed greater absolute theta band power in the areas studied.

Keywords: Cybersikness; Inhibitory control; No-Go; EEG; Absolute theta power.

\section{Resumo}

O cybersickness resulta do conflito do vestíbulo visual, ou seja, da incoerência entre as sensações relacionadas ao movimento real, no ambiente virtual, e os estímulos visuais. Em resposta ao ambiente virtual, podem-se observar desconfortos como náuseas, dificuldade de concentração e dores de cabeça, entre outros. Não existem estudos na literatura que analisem o controle da inibição de estímulos luminosos em indivíduos sensíveis à Cibersickness. Portanto, este estudo avaliou o controle da inibição do estímulo de luz no Cybersickness. O Sickness Susceptibility Questionnaire foi utilizado para dividir os sujeitos em grupos experimental e controle e quantificar os sinais e sintomas, comparandoos antes e após a imersão virtual 3D. Os participantes em ambos os grupos foram examinados com EEGq para a potência da banda theta absoluta no córtex pré-frontal dorsolateral e córtex pré-frontal ventrolateral durante a tarefa de inibição do estímulo de luz antes e depois que os participantes assistiram ao vídeo 3D. Os resultados parciais mostraram que houve aumento da potência absoluta da banda theta nos dois grupos na comparação dos momentos antes e depois, bem como diferença significativa no grupo experimental em relação ao controle, para o mesmo momento. Assim, observouse que indivíduos que foram expostos à realidade virtual 3D e desenvolveram Cybersikness, apresentaram maior potência absoluta da banda theta nas áreas estudadas.

Palavras-chave: Cybersikness; Controle inibitório; No-Go; EEG; Poder theta absoluto.

\section{Resumen}

El cibersickness es el resultado del conflicto del vestíbulo visual, es decir, la incoherencia entre las sensaciones relacionadas con el movimiento real, en el entorno virtual, y los estímulos visuales. En respuesta al entorno virtual, se pueden observar molestias como náuseas, dificultad para concentrarse y dolores de cabeza, entre otros. No existen estudios en la literatura que analicen el control de la inhibición de los estímulos lumínicos en individuos sensibles al Cybersickness. Por lo tanto, este estudio analizó el control de la inhibición del estímulo lumínico en el Cybersickness. Se utilizó el Cuestionario de Susceptibilidad a la Enfermedad para dividir a los sujetos en grupos experimentales y de control, y cuantificar los signos y síntomas, comparándolos antes y después de la inmersión virtual 3D. Los participantes de ambos grupos fueron examinados con EEGq para determinar el poder absoluto de la banda theta en la corteza prefrontal dorsolateral y la corteza prefrontal ventrolateral durante la tarea de inhibición del estímulo de luz antes y después de que los participantes vieran el video en 3D. Los resultados parciales mostraron que hubo un aumento en la potencia absoluta de la banda theta en ambos grupos comparando los momentos antes y después, así como una diferencia significativa en el grupo experimental en comparación con el control, para el mismo momento. Así, se observó que los individuos que fueron expuestos a la realidad virtual 3D y desarrollaron Cybersikness, mostraron un mayor poder absoluto de banda theta en las áreas estudiadas.

Palabras clave: Cybersikness; Control inhibitorio; No-Go; EEG; Poder theta absoluto.

\section{Introduction}

The virtual environments use as a treatment, in the field of research, has been advancing rapidly by allowing the study of situations, reactions, and/or pathologies in a safe environment minimizing or eliminating possible risks (Pennel \& Charron, 2015; Garret et al., 2018; Levac et al., 2019; Litleskare et al., 2020; Birenboim et al., 2021). The intact vestibular apparatus of healthy individuals may exhibit symptoms related to kinetosis, according to provoking stimulus in quantity and quality, although there are individual differences regarding the susceptibility degree (Schmal, 2013; Byagowi et al., 2014). Kinesthesia or Motion Sickness is conceptualized as a sensory conflict between the vestibular, proprioceptive, and visual systems during movement, whether real or virtual. For example, when the individual experiences trip in cars, buses, ships, or even in virtual environments that occur trips simulation (França \& Branco-Barreiro, 2013; Koch et al., 2018; Leung \& Hon, 2019). This conflict is characterized by triggering a cascade of signs and symptoms, such as nausea, vomiting, cold sweating, pallor, burping, drowsiness, fatigue, oculomotor disorders, among others (Gavgani et al., 2016; Golding, 2016).

The sensory conflict theory elucidates that kinetosis is caused by incompatibility between the movement perceived through vision and the signals received from the vestibular system, based on the previous movement experience (Ganança et al., 2014). More specifically, Virtually Induced Movement Disorder (DMVI) adheres to the same concept as sensory conflict, 
because in other words, this is kinetosis that occurs in the virtual environment. DMVI has typical symptoms like those of Kinetosis, although it presents vomiting more rarely (Golding, 2016; Gavgani et al., 2017). There are a few different nomenclatures for DMVI types, classifying them as Cybersickness, the DMVI in a virtual environment; DMVI during a video game, known as Gaming Illness and as Simulator Illness, when this DMVI occurs inside a simulator (Kennedy et al., 1997; Keshavarz et al., 2015).

Cybersickness results from vestibule-visual conflict, due to the incoherence between the sensations related to real movement in the virtual environment and the visual stimulus (Malinska et al., 2015). Symptoms such as nausea and eye fatigue, arising from this conflict tend to cause impairment to individuals' experience in the virtual environment, as well as the execution of visual tasks performed by them (Chen et al., 2015). The Sickness Susceptibility Questionnaire (SSQ) is a tool that is used to quantify and distribute in domains, the symptoms that can be developed in a virtual environment and make it possible to make comparisons to define if the individual has developed Cybersickness (Carvalho et al., 2011; Chaumillon et al., 2017).

Due to the symptoms of individuals who develop Cybersickness and its relation with the difficulty of developing visual tasks, tasks that involve the Saccadic Eye Movement (MOS) become relevant to be studied (Chen et al., 2015; Freitas et al., 2018). MOS consists of a rapid eye movement that can be voluntary or reflex, responsible for capturing the image of interest and then projecting it onto the fovea. Abnormalities in MOS can be seen in a variety of disorders, such as those associated with the vestibular system, as well as psychopathologies. Furthermore, by evaluating MOS during inhibition of the light stimulus when using the No-Go paradigm, it is possible to analyze the control of this stimulus (Bittencourt et al. 2012; Velasques et al., 2013; Balconi et al., 2017; Buonocore et al., 2017).

Some studies with electroencephalography (EEG) have analyzed the Cybersikness electroneurophysiology (Kim et al., 2005; Chen et al., 2015; Koslucher et al., 2016), however, there are no studies in the literature that have analyzed EEG during the visual stimulus task of inhibition, thus justifying this study. Additively, in the study by Naqvi and colleagues (2015), individuals who watched 3-dimensional (3D) and 2-dimensional (2D) movies were compared concerning the symptoms that the virtual environment could induce. Both groups (2D and 3D) watched 10 minutes of a film aimed at inducing Cybersickness, the films simulated a car moving along a road. They used SSQ to quantify the symptoms.

In this scene, the individuals who watched the 3D movie observed significantly greater symptoms compared to those in the $2 \mathrm{D}$ group. In the EEG we observed a positive correlation with the absolute theta band power (PAT) in the frontal region, due to its relationship with the Cybersikness symptoms expansion. Thus, the PAT analysis importance (Park et al., 2008; Naqvi et al., 2015) in these individuals is highlighted. The increased PAT (4.5 - 8) may be related to the sensory-motor activity coordination and visuospatial attention, as well as also, to the light stimulus inhibition control (Cartier et al., 2015; Bae et al., 2016; Zhang et al. 2017). Therefore, this study aims to analyze the absolute theta band power in the light stimulus inhibition task, in individuals induced to Cybersickness.

\section{Materials and Methods}

\subsection{Participants}

The sample contains 32 female participants, healthy, aged between 18 and 28 years, with a mean of 23.28 and standard deviation \pm 3.22 , right-handed based on the Edinburgh Manual Inventory (Seidman et al, 2013), selected through individual disclosure and/or invitation in the classrooms of the Federal University of Piauí (UFPI), Parnaíba's Campus. The participants were clarified about the research purpose, objectives, procedures, and consulted regarding the acceptance to participate in the study. The research confidentiality and the right to withdraw from participation, at any time during the study, was assured. Finally, the participants were instructed to sign the Informed Consent Form (ICF). The study was carried out in the Brain 
Mapping and Functionality Laboratory (LAMCEF) of UFPI and approved by the Research Ethics Committee of the Federal University of Piauí, No. 1.806.547.

\subsection{Inclusion Criteria}

We included female volunteers without uncorrected neurological, vestibular, and visual pathologies, who did not use psychoactive drugs or muscle relaxants and had not used products containing caffeine or central nervous system stimulants in the 12 hours before data collection and who had slept more than 6 hours the night before the experiment. For the Cybersikness Group (CG), participants with total severity score variation in the SSQ, comparing the moments before and after virtual immersion, above 15 and below or equal to this value were included to the Control Group (CG) (Kennedy et al., 2003).

\subsection{Experimental Procedure}

The experiment (Figure 1) started after a screening where personal data were collected, such as: name, gender, age, contact, use of medication, whether they had neurological and/or vestibular diseases and visual acuity. Soon after, the Edinburgh Manual Inventory was applied (Seidman et al, 2013). Then, the MSSQ (Golding, 1998) was used in order to observe the susceptibility of the individual to kinetosis, and the SSQ (Kennedy et al., 2003) to determine the group to which the participants would be directed, according to what was established on the total severity score variation between the moments before and after the 3D Virtual Reality (VR), since the variation above 15 directed the participants to the EG and if equal to or below this value to the CG (Kennedy et al. 2003).

During the experiment, the subjects were asked to sit comfortably on a chair with arm support, to minimize muscle artifacts. In front of the participant was placed a 13-bar composed Light Emitting Diode (LED), positioned at the height of the participant's eyes, at $100 \mathrm{~cm}$. The bar is composed of 6 LEDs on the left side and 6 on the right side, and a warning (central bicolor LED). They were then given instructions as to how to conduct the experiment. It was explained that the warning would light in two different colors, green or red, and after the warning was turned on, one of the LEDs on the right or left would light (Figure 2).

Figure 1: Collection Steps.

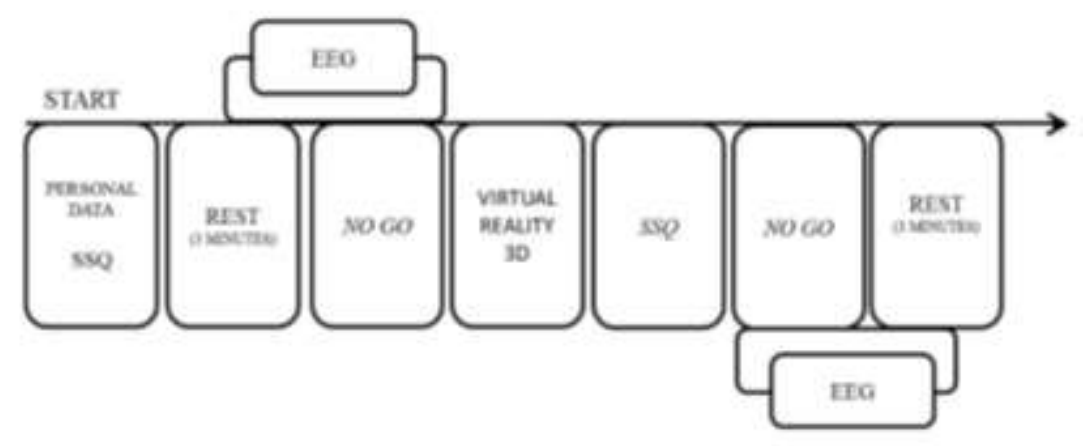

Source: Authors.

The participants were asked to keep their eyes fixed on the bar center and only change the direction of their gaze after the warning was turned on. So that when the warning was red, the participant should inhibit the MOS so that it would not follow the next onset, and when the warning was green, the participant should direct her gaze to the side LED, which would then light up. It was also clarified that only the gaze should follow the stimulus, and the head should remain inert. During the entire use of the LED bar and in the resting moments, before and after the 3D VR, the electroencephalographic signal was captured in the 
GSC and CG. The bar exposure had, in each block, a duration of 1.46s, with the parameters, baseline interval and onset duration, respectively of $2 \mathrm{~s} \times 250 \mathrm{~ms}$, in alternating random mode. The light stimulus inhibition task was performed at two time points with 6 blocks of 120 trails in total. Two rests were performed, at the beginning and at the end of the experiment, lasting 3 min each.

The 3D VR lasted $16 \mathrm{~min} 35 \mathrm{~s}$, with a video display simulating that the participant was on a roller coaster at an amusement park. Every 5 minutes they were asked about the level of dizziness, according to the Modified Visual Analog Scale (VAS) for motion sickness, with a score variation from 0 to 10, which was previously presented. They were also asked about the occurrence of nausea and malaise. A safety band was used, according to the VAS, where the score 8 was the maximum allowed, since 9 and 10 indicated severe discomfort during virtual immersion, indicating the need to interrupt the virtual immersion. The experiment was interrupted upon request by the participant or observation by the researchers regarding signs that indicated any risk of vomiting and/or fainting, in order to preserve the participants.

Figure 2: Participant positioned for EEG signal acquisition.

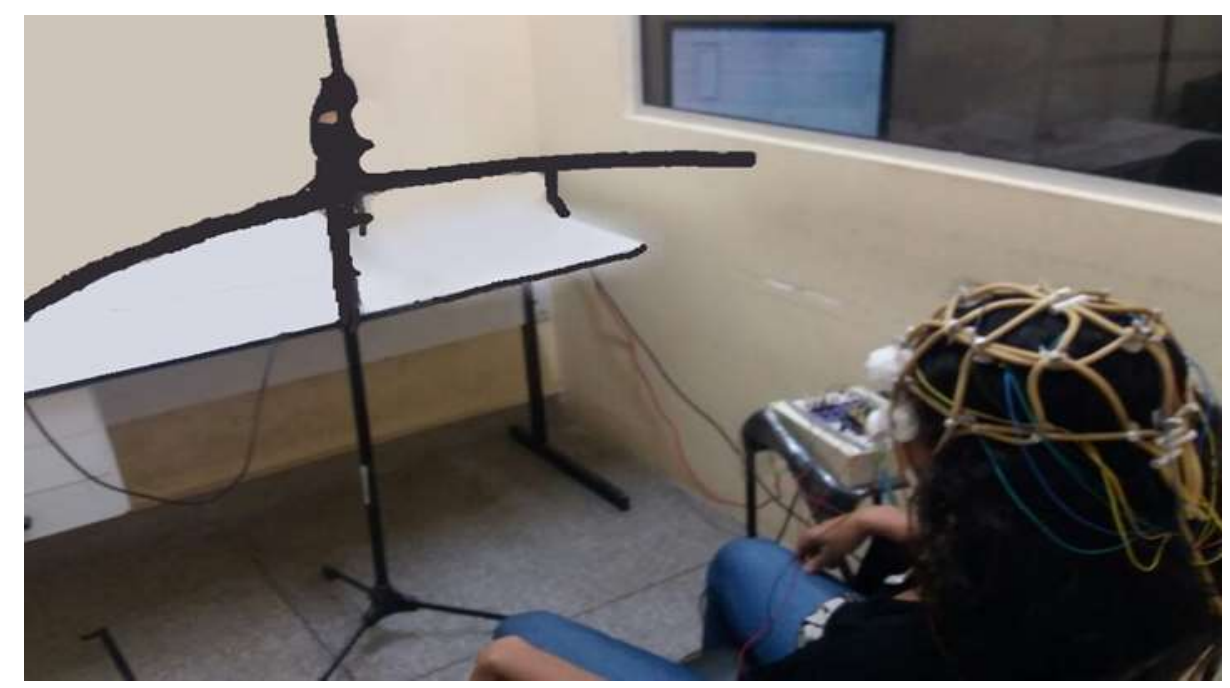

Source: Authors.

The instruments used for virtual immersion were the 3D Matte Vr Shinecon 2.0 Vr black VR glasses and the Samsung J5 cell phone, attached for video display. To capture the EGG signal we used a BrainNet BNT-EEG device (EMSA - Medical Instruments, Brazil) with a 20-channel analog-to-digital (A/D) converter board with 16-bit resolution. The electrodes were arranged following the 10-20 international system, including reference electrodes positioned on the earlobes (bi-auricular), lateral oculars (1 pair), in both corners of the eyes, and vertical (1 pair), one upper and one lower.

\subsection{Data processing}

\section{Electrophysiological Signals}

The EEG signal analysis was performed using the EEGLAB/MATLAB program in EEGq. It was comprised in a total window of $2 \mathrm{~s}$, for visualization of the process during the No-Go warning LED, in the moments before and after, the 3D VR, comprised the epoch from $-1 \mathrm{~s}$ to $1 \mathrm{~s}$. The data contained in the epochs were bandpass filtered (0.5 to $40 \mathrm{~Hz})$. The electrodes used for analysis were F3, F4, F7 and F8. Since, the capture room had acoustic isolation and electrical grounding. The impedance of the skin-electrode interface was kept below $5 \mathrm{k} \Omega$. The acquired data had a total amplitude of less than $100 \mathrm{mV}$. The EEG signal was filtered between $0.5 \mathrm{~Hz}$ (high-pass) and $40 \mathrm{~Hz}$ (low-pass), filtering noting $60 \mathrm{~Hz}$, sampling at rest $400 \mathrm{~Hz}$ and task $200 \mathrm{~Hz}$, with 
Sacadic Aquisition software. The collected data were transformed (re-referenced) using the average reference, and then were conducted for artifact elimination with ICA (Independent Component Analysis). By visual inspection, tracks clearly demonstrating blinks and saccade-related artifacts were removed.

\subsection{Statistical analysis}

\subsubsection{Behavioral}

In data analysis referring to the SSQ, after it was observed that it did not have a normal distribution by means of the Shapiro Wilk test, besides not having homogeneity of variances, according to Levene's Test. The Mann-Whitney test was used to analyze whether there was a statistically significant difference between the groups (CG and EG) and time (before and after) in the domains: Nausea, Oculomotor, Disorientation and Total Score. And the Wilcoxon test to observe if there was a statistically significant difference for the moments before and after within each group (CG and EG) in the domains (Nausea, Oculomotor, Disorientation, and Total Score), with the Bonferroni correction considered $\mathrm{p}<0.003$, for statistically significant differences.

\subsubsection{Electrophysiological}

As for the electrophysiological data, to verify the absolute theta band power variation related to the epoch from -1s to 1s, to the No-Go warning LED to be observed at the moments before and after the 3D VR, in the CG and EG and in the electrodes F3, F4, F7, F8. Initially the data were parametrized, outliers removed, with the Shapiro Wilk test it was observed that the data were normally distributed $(p>0.05)$. It was assumed that there was no variances homogeneity. The Three Way Anova test was used to analyze the statistically significant difference between group, moment, and area, where a double interaction was observed between group and moment and moment and area. The Student's t-test was used to analyze interactions, with $\mathrm{p}<0.025$ considered statistically significant after applying the Bonferroni correction. The analysis was conducted using SPSS for Windows version 21.0 .

\section{Results}

\subsection{Behavioral}

The Mann-Whitney test showed statistically significant difference between group and moment, for the moment after, in the Nausea domains $(U=7 ; p<0.0001)$, Oculomotor $(U=36.5 ; p<0.0001)$, Disorientation $(U=24.5 ; p<0.0001)$ and Total Score $(U=18.5 ; p<0.0001)$. Wilcoxon's test, on the other hand, showed the statistically significant difference for the moments before and after $E G$, in the Nausea domains $(Z=-3.518$; $p<0.0001)$, Oculomotor $(Z=-3.344 ; p<0.001)$, Disorientation $(Z=-$ 3.416; $\mathrm{p}<0.001)$, Total Score $(Z=-3.518 ; \mathrm{p}<0.0001)$ (Figure 3). 
Figure 3: Demonstrates by means of the median SSQ scores within each domain for CG and EG, at the moments before and after $(\mathrm{a}, \mathrm{d})$ the 3D VR. * significant difference between the moments before and after intra-group, for the domains (DN, DO, DD) and total score (ET); + significant difference in DN-d between the groups, $\triangle$ significant difference in DO-d between the groups; $\triangle$ significant difference in DD-d between the groups; $\square$ significant difference in ET-d between the groups; considering $\mathrm{p}<0.05$.

\section{Sickness Susceptibility Questionnaire}

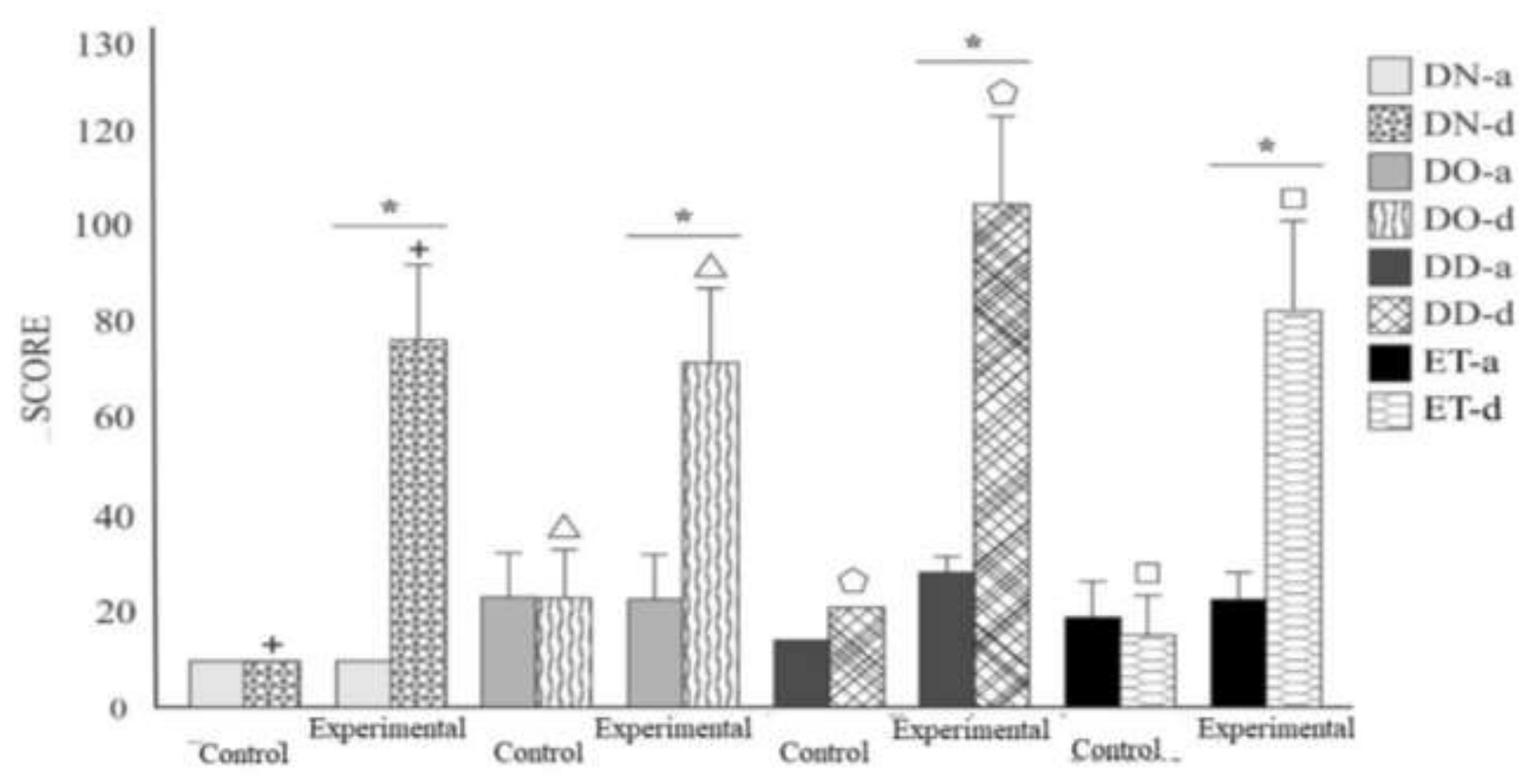

Source: The authors.

\subsection{Electrophysiological}

A Three Way Anova was performed for group (control and experimental), moment (before and after) and areas (F3, F4, $\mathrm{F} 7, \mathrm{~F} 8)$ interaction was observed between moment and group $\left[\mathrm{F}(1,1,000)=4.072, \mathrm{p}=0.04, \mathrm{n}^{2} \mathrm{p}=0.002\right.$, power $\left.=52 \%\right]$ and an interaction between area and group $[\mathrm{F}(3,1,000)=16.972, \mathrm{p}<0.001$, power $=100 \%]$. In the analysis between moment and group, the t-test pointed out a difference in the control group, between the moment before and after, only for Right Dorsolateral Prefrontal Cortex $(\mathrm{F} 4)[\mathrm{t}(872)=2.921, \mathrm{p}=0.004, \mathrm{~d}=0.098]$ and in the experimental group also for Right Dorsolateral Prefrontal Cortex or $\mathrm{F} 4[\mathrm{t}(873)=2.241, \mathrm{p}=0.025, \mathrm{~d}=0.075]$. When assessing the interaction between time and area a difference was observed at the time before for the groups in Left Dorsolateral Prefrontal Cortex or F3 [t $(1663)=6.312, p<0.001, d=6.31]$, Right Dorsolateral Prefrontal Cortex or F4 [ t (1636) = 8. 768, p<0.001, d = (8.76)], Left Ventrolateral Prefrontal Cortex or F7[t $(1403)=4.388, \mathrm{p}<0.001, \mathrm{~d}=4.38]$ and Right Ventrolateral Prefrontal Cortex or F8 $[\mathrm{t}(1311)=6.728, \mathrm{p}<0.001, \mathrm{~d}=6.72]$. Whereas, at the later time point, a statistically significant difference was observed for Left Ventrolateral Prefrontal Cortex or $\mathrm{F} 7[\mathrm{t}(1,619)=4.011, \mathrm{p}<0.001, \mathrm{~d}=(4.01)]$ and Right Ventrolateral Prefrontal Cortex or F8 $[\mathrm{t}(1,554)=4.347, \mathrm{p}<0.001, \mathrm{~d}=$ 4.347] (Figure. 4). 
Figure 4: Shows the absolute theta band power in dorsolateral prefrontal cortex and ventrolateral prefrontal cortex by mean and standard deviation, between CG and EG at the moments before and after (a, d) 3D VR. * significant difference between the moments before and after intra-group, for area; $\square$ significant difference in CPFDLe-a between groups; $\triangle$ significant difference in CPFDLd-a between groups; $\triangle$ significant difference in CPFVLe-a between groups; $\diamond$ significant difference in CPFVLe-d between groups; $\circ$ significant differences in CPFVLd-a between groups; $\uparrow$ significant differences in CPFVLd-d between groups.

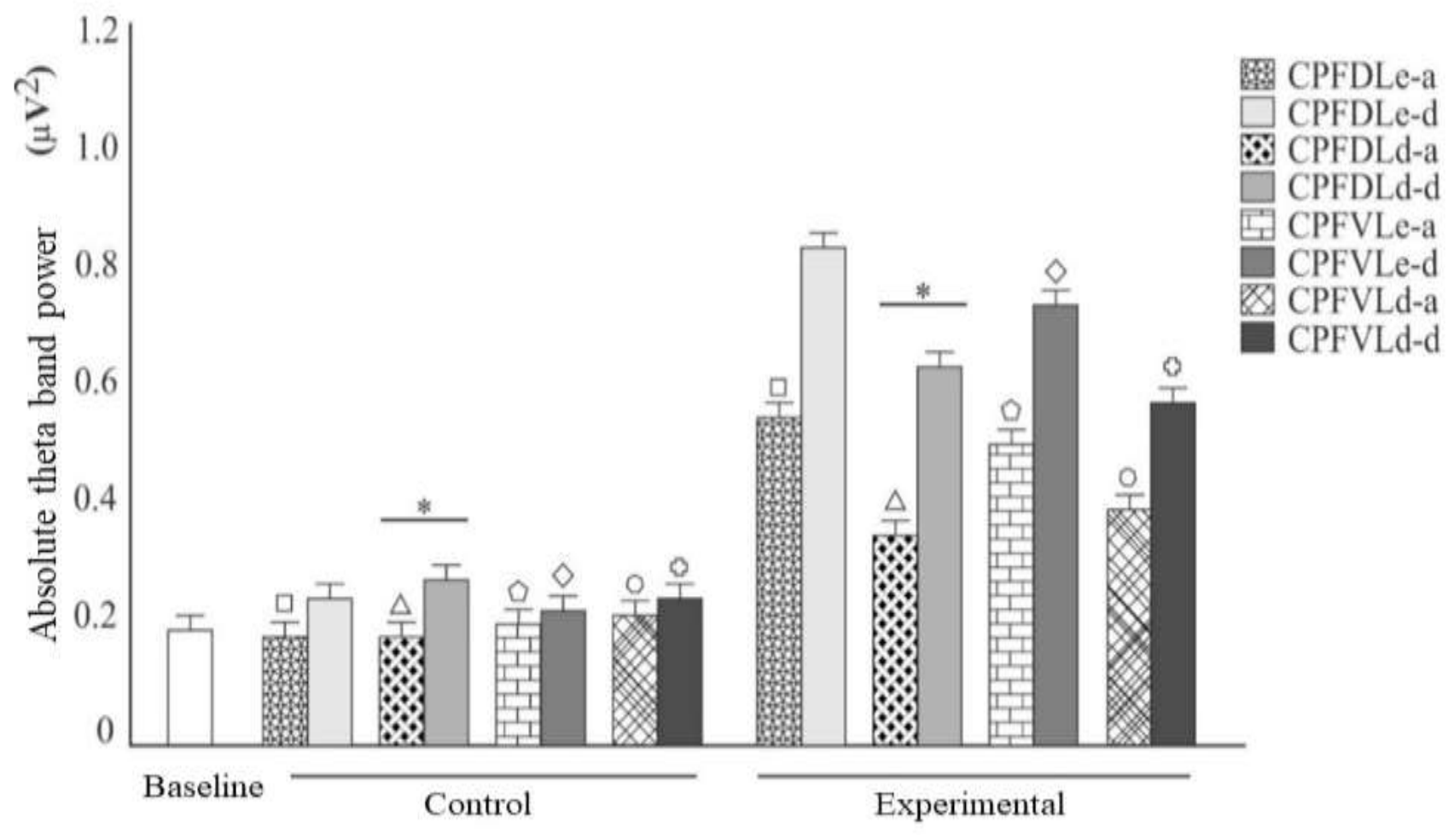

Source: The authors.

\section{Discussion}

The present experiment investigated changes in PAT analyzed by EEGq means related to the inhibition control process in the light stimulus inhibition task, using the No-Go paradigm. We analyzed the theta band in female subjects, who were induced to develop the Cybsikness symptoms, which were triggered by means of 3D VR. PAT behavior was observed in areas of the scalp representing CPFDL (F3-F4), CPFVL (F7-F8) in both groups, i.e., those who developed Cybersikness and those who did not, EG and CG respectively. The use of 3D VR, in this study, was justified in the discomforts generated in the individuals submitted to it were relevant, especially in those prone to develop Cybersikness symptoms. In particular, the quantification of these symptoms was established by SSQ means, in scores, this being the behavioral study variable. The variation in scores was used as a means of defining the groups, with the CG containing participants who did not develop symptoms, according to the scores, and the EG containing those who did.

Some participants during exposure to 3D VR were unable to remain watching the movie for all $16 \mathrm{~min} 35 \mathrm{~s}$, which was its total duration, and was also one of the requirements for the participants to continue in this study. However, as initially established, the participants would not be exposed to severe discomfort, to protect their integrity. Two individuals dropped out of the experiment during the virtual immersion, reporting intense headache and strong nausea, indicating 9 on the VAS for nausea. Such fact, reinforces about the duration of immersion to 3D VR being sufficient, reaching what was expected within this study, aiming to stimulate the symptoms of Cybersikness (Gavgani et al., 2016; Bos et al., 2018). 
Analyzing the data related to the SSQ, a statistically significant difference was observed when comparing the moments before and after 3D VR in the EG. In the CG, comparing the same moments, no significant differences were observed after immersion in 3D VR, which establishes that the participants from the EG manifested a greater range of symptoms, quantified by means of the SSQ scores, after watching the video in virtual immersion. This result is within expectation, since in the EG all the individuals developed Cybersikness. Therefore, it is due to 3D VR the triggering of the related symptoms in the subjects of the EG, since they proved to be sensitive to this exposure. Studies corroborate the results of the present study, since it has been observed that some individuals feel discomfort when using VR devices, such as eye fatigue, nausea, among others, which are also common. As for the score, it was established that the higher it was, the more symptoms were developed and/or the greater was their intensity, for this reason the increase of the same symptoms was not observed significantly, after 3D virtual immersion in the CG (Carnegie \& Rhee 2015; Han et al. 2017; Keshavarz et al., 2018).

According to some studies, healthy individuals are likely to develop symptoms such as disorientation, nausea, eye fatigue, belching, headache, vertigo and etc, during and after exposure to 3D VR, for up to 5 hours. Since, when they develop this cascade of symptoms in virtual environment the individual presents Cybersiknness (Carvalho et al., 2011; Treleaven et al., 2015). In this study, the SSQ score was also compared between the groups of individuals, those who developed and those who did not develop Cybersikness at times before and after 3D VR. It was observed that at the time before both groups had no statistically significant differences, which reinforces about the individuals initially being equal when compared, as they had no symptoms establishing Cybersikness before watching the video. However, after exposure to 3D VR, there were significant differences when comparing the CG and EG, as we observed higher scores, referring to more symptoms in the EG, due to exposure to 3D VR. The result of the present study is in accordance with the literature, since the emergence and/or increase in the intensity of symptoms related to Cybersikness are observed after exposure to 3D VR in specific individuals (Malińska et al., 2014; Biernacki et al., 2016).

In the electrophysiological data analysis, there was interaction between time and group. Both in the CG and EG when comparing the moments before and after, within each group, there was an increase in PAT after 3D VR, in all areas studied, i.e., in the right and left CPFDL, as well as in the right and left CPFVL also, although among these results it was significant only the one referring to the PAT of the right CPFDL, when comparing the moments before and after VR, which according to studies is justified because the CPFDL and CPFVL play different roles in preparation for inhibition. Since the CPFDL focuses on the goal of the task itself and its activation occurs prior to the stop, while the VLPFC can implement action control, participating later, right at the time related to task preparation for inhibition of the light stimulus (Chikazoe, 2010; Swann et al., 2013; Bruni et al., 2015).

The PAT increase in the frontal region is observed during MOS-related activities, more specifically the task of inhibiting the light stimulus, as well as the control of this stimulus, since the frontal region acts in inhibiting the execution of individuals' functional actions (Petit et al. 2012; Detandt et al. 2017; Maij et al. 2017). Although, the Cybersikness symptoms exacerbations, are also related to the increase in PAT, something that was already observed in both groups by means of the SSQ, which allows suggesting that this increase is not only related to the Cybersikness symptoms exacerbation, but also to the inhibitory control, which was observed during the task of inhibition of the light stimulus (Knyazev, 2010; Zhou et al., 2016; Liu et al., 2017; Huster et al., 2013; Herrmann et al., 2016).

This study also showed an interaction between moment and area, with a statistically significant difference in PAT between the CG and EG comparing them at the moment before in the CPFDL and CPFVL areas, i.e., in all areas analyzed in this study. The subjects in the EG, during the light stimulus inhibition task had higher PAT, even though at this moment both groups were equal in relation to symptoms, since there was no presence of Cybersikness symptoms, because they had not yet undergone 3D VR to present symptoms, the referred group had higher PAT compared to the CG. The increased PAT observed in the EG 
suggests that, the inhibition control of the light stimulus was significantly higher compared to the CG, prior to immersion in 3D VR. In a manner, not yet established in the literature, because the light stimuli inhibitory control relationship in individuals susceptible to developing the Cybersikness symptoms has not yet been investigated. The result of this study suggests that individuals, even at the time when they do not present the Cybersikness symptoms, only in being sensitive to Cybersikness during light stimulus inhibition show higher PAT in CPFDL and CPFVL, suggesting greater inhibitory control in these individuals (Knyazev 2010; Swann et al., 2013; Cartie et al. 2015;).

After 3D VR, comparing the CG and EG to light stimulus inhibition, although in all areas studied there was a higher PAT for the EG, this difference was only significant in the right and left CPFVL. This corroborates the suggestion that individuals exposed to 3D VR who develop Cybersikness symptoms tend to have a greater inhibitory control of light stimuli, even when they did not show symptoms, i.e., before the induction of Cybersikness, as well as in the presence of symptoms. When observing, the moment before, such results elucidate that although, the individuals had not yet been exposed to 3D VR and developed Cybersikness, possibly the sensory inadequacy of the vestibular, visual, and proprioceptive system generated, induces these results, observed with increased PAT in the EG (Bair, 2017; Liu et al., 2017; Buonocore et al., 2017; Freitas et al., 2018).

\section{Conclusion}

The present study aimed to analyze the individuals PAT who were induced to Cybersikness through 3D VR, during the task inhibition of light stimulus for the moment before virtual immersion and after, comparing the results of the participants who developed Cybersikness with those who did not. The participants who were exposed had the development of more symptoms and were also more intense, besides having presented higher PAT in all the areas studied. Therefore, it can be concluded that individuals exposed to 3D VR who develop Cybersikness show higher PAT in CPFDL and CPFVL when compared to individuals who do not develop the same symptoms, whether considering the moment before 3D virtual immersion or after analyzing the electrocortical activity of these individuals during inhibition of the light stimulus.

The results elucidate that the increase in PAT in CPFDL and CPFVL is not only related to the onset and/or intensification of symptoms, but also to greater control during the task of inhibiting the light stimulus, since higher PAT was observed in Cybersikness-sensitive individuals at all studied time points. The small sample size is a limitation of this study. Further studies on the subject should be carried out with a larger sample in to analyze the PAT variation in frontal cortex areas through inhibition tasks in individuals sensitive to Cybersikness.

For future development of works with a better methodological adjustment, we made some notes, namely: researching other ranges of brain activities, inclusion of a placebo group to better verify the effects, increase the number of participants for a better representation of the population, and finally would optimize the experimental design including a sample randomization.

\section{References}

Bae, Y. (2016). Saccadic Eye Movement Improves Plantar Sensation and Postural Balance in Elderly Women. The Tohoku Journal of Experimental Medicine, 239(2): 159-164.

Balconi, M., Campanella, S., \& Finocchiaro, R. (2017). Web addiction in the brain: Cortical oscillations, autonomic activity, and behavioral measures. Journal of Behavioral Addictions, 6(3): 334-344.

Bastos, V. H., Cunha, M., Veiga, H., Mcdowell, K., Pompeu, F., Cagy, M., Piedade, R., \& Ribeiro P. (2004). Analysis of cortical power distribution as a function of learning to type. Rev. Bras Med Esporte, 10: 500-504.

Biernacki, M. P., Kennedy, R. S., \& Dziuda, L. (2016). Simulator sickness and its measurement with Simulator Sickness Questionnaire (SSQ). Medycyna Pracy, 67(4): 545-555.

Birenboim, A., Ben-Nun, B. P., Levit, H., \& Omer, I. (2021). The Study of Walking, Walkability and Wellbeing in Immersive Virtual Environments. Int J Environ Res Public Health, 18(2): 364. 
Bittencourt, J., Machado, S., Teixeira, S., Schlee, G., Salles, J. I, Budde, H., \& Sack, A. T (2012). Alpha-band power in the left frontal cortex discriminates the execution of fixed stimulus during saccadic eye movement. Neuroscience letters, 523(2): 148-153.

Bittencourt, J., Velasquez, B., Teixeira, S., Basile, L. F, Salles, JI, Nardi, A. E, \& Ribeiro, P. (2013). Saccadic eye movement applications for psychiatric disorders. Neuropsychiatric disease and treatment, 9: 1393-1409.

Blair, C. (2017). Educating executive function. Wiley Interdiscip. Rev CognSci, 8: 1-2.

Bos, J. E. et al. (2018). Motion sickness in motion: from carsickness to cybersickness. Nederlands tijdschrift voor geneeskunde, 162: D1760-D1760.

Brandalize, D., Rodacki, A. L. F, \& Israel, V. L (2010). Postural Control After Exposure to Sensory Conflict. Revista Brasileira de Biomecânica, 11(21): 2329.

Brandalize, D., Rodacki, A. L. F., Brandalize, M., \& Israel, VL (2012). Chronic Exposure in an Environment of Sensory Conflict and its Influence on Postural Control. Motriz, 18(4): 721-727.

Brass, M., Rigoni, D., \& Haggard, P. (2014). Intentional inhibition: from motor suppression to self-control. Neuropsychologia, 65: $234-235$.

Bronstein, A. M., Golding, J. F., \& Gresty, M. A (2013). Vertigo and dizziness from environmental motion: visual vertigo, motion sickness, and drivers' disorientation. In: Seminars in neurology. Thieme Medical Publishers, 219-230.

Bruni, S. et al. (2015). Processing and integration of contextual information in monkey ventrolateral prefrontal neurons during selection and execution of goaldirected manipulative actions. Journal of Neuroscience, 35(34): 11877-11890.

Buonocore, A., Purokayastha, S., \& Mcintosh, R. D (2017). Saccade Reorienting Is Facilitated by Pausing the Oculomotor Program. Journal of Cognitive Neuroscience, [Epub ahead of print].

Byagowi, A., Mohaddes, D., \& Moussavi, Z. (2014). Design and Application of a Novel Virtual Reality Navigational Technology (VRNChair). J Exp Neurosci, r 2(8):7-14

Carnegie, K., \& Rhee, T. (2015). Reducing visual discomfort with HMDs using dynamic depth of field. IEEE computer graphics and applications, 35(5): 3441 .

Cartier, C., Diniz, C., Di Girogio, L., Bittencourt, J., Gongora, M., Tanaka, G. K, \& Da Silva, R. D. A (2015). Changes in Absolute Theta Power in Bipolar Patients During a Saccadic Attention Task. Psychiatry research, 228(3): 785-790.

Carvalho, M. R, Costa, R. T, \& Nardi, A. E. (2011). Simulator Sickness Questionnaire: Tradução e Adaptação Transcultural. J Bras Psiquiatr, 60(4): $247-52$.

Cavanagh, J. F, \& Frank, M. J. (2014). Frontal theta as a mechanism for cognitive control. Trends CognSci,18: 414-421.

Chan, J. L, \& De Souza, J. F. X. (2013). The effects of attentional load on saccadic task switching. Experimental brain research, $227(3)$ : 301-309.

Chaumillon, R., Romeas, T., Paillard, C., Bernardin, D., Giraudet, G., Bouchard, JF, \& Faubert, J. (2017). Enhancing Data Visualisation to Capture the Simulator Sickness Phenomenon: On the Usefulness of Radar Charts. Data in Brief, 13: 301- 305.

Chelen, W. E, Kabrisky, M., \& Rogers, S. K. (1993). Spectral analysis of the electroencephalographic response to motion sickness. Aviation, space, and environmental medicine, 64(1): 24-29.

Chen, DJ, Bao, B., Zhao, Y., \& So, RH. (2015). Visually Induced Motion Sickness when Viewing Visual Oscillations of Different Frequencies Along the Foreand-Aft Axis: Keeping Velocity Versus Amplitude Constant. Ergonomics, 59(4): 1-9.

Chikazoe, J. (2010). Localizing performance of go/no-go tasks to prefrontal cortical subregions. Current opinion in psychiatry, 23(3): 267-272.

Dahlman, J., Sjörs, A., Ledin, T., \& Falkmer, T. (2008). Could Sound Be Used as a Strategy for Reducing Symptoms of Perceived Motion Sickness? Journal of neuroengineering and rehabilitation, 5(1): 35 .

Detandt, S., Bazan, A., Schröder, E., Olyff, G., Kajosch, H., Verbanck, P., \& Campanella, S. (2017). A Smoking-Related Background Helps Moderate Smokers to Focus: an Event-Related Potential Study Using a Go-Nogo Task. Clinical Neurophysiology, 128(10): 1872-1885.

Diels, C., \& Howarth, P. A. (2013). Frequency Characteristics of Visually Induced Motion Sickness. Human Factors, 55(3): 595-604.

Dennison, M. S., \& D'zmura, M. (2017). Cybersickness without the wobble: Experimental results speak against postural instability theory. Applied ergonomics, 58: 215-223.

Dorigueto, R. S., Kasse, C. A., \& Silva, R. C. (2012). Cinetose. Revista Equilíbrio Corporal e Saúde, 4(1): 51-58.

Drummond, P. D., \& Granston, A. (2004). Facial pain increases nausea and headache during motion sickness in migraine sufferers. Brain, 127(3): 526-534.

França, S. R., \& Branco-Barreiro, F. C. A. (2013). Susceptibility to kinetosis in the elderly with vestibular disease. Journal Body Balance and Health, 5(1): 3035 .

França, S. R., Pereza, M. L. V. D., Scharlachb, R. C., \& Branco-Barreiro, F. C. A. (2016). Susceptibility to kinetosis in schoolchildren. Rev. Equilíbrio Corporal Saúde, 7(2): 47-50.

Freitas, F. S. A. et al. (2018). The Inhibitory Control in the Cybersickness and Saccadic Ocular Movement as a Parameter”. EC Neurology SI, 1: 40-42. 
Ganança, F. F, Ganança, C. F, De Ávila Pires, A. P. B., \& Duarte, J. A. (2014). Virtual Reality for the Treatment of Kinetosis: Preliminary Results. Journal Body Balance and Health, 6(1): 3-10.

Garrett, B., Taverner, T., Gromala, D., Tao, G., Cordingley, E., \& Sun, C. (2018). Virtual Reality Clinical Research: Promises and Challenges. JMIR Serious Games, 6(4): e10839.

Gavgani, A. M., Nesbitt, K. V., Blackmore, K. L., \& Nalivaiko, E. (2017). Profiling Subjective Symptoms and Autonomic Changes Associated with Cybersickness. Autonomic Neuroscience, 203: 41-50.

Gavgani, A. M., Hodgson, D. M., \& Nalivaiko, E. (2017). Effects of Visual Flow Direction on Signs and Symptoms of Cybersickness. PloS one, 12(8): e0182790.

Gavgani, A. M., et al. (2018). Cybersickness-related changes in brain hemodynamics: A pilot study comparing transcranial Doppler and near-infrared spectroscopy assessments during a virtual ride on a roller coaster. Physiology \& behavior, 191: 56-64.

Golding, J. F. (2016). Motion Sickness. Handbook of Clinical Neurology, 137(3): 372-390.

Golding, J. F. (1998). Motion sickness susceptibility questionnaire revised and its relationship to other forms of sickness. Brain Research Bulletin, 47(5): 507516.

Grunfeld, E., \& Gresty, M. A. (1998). Relationship Between Motion Sickness, Migraine and Menstruation in Crew Members of a "Round The World" Yacht Race. Brain research bulletin, 47(5): 433-436.

Guo, C. C. T., et al. (2017). Correlations between individual susceptibility to visually induced motion sickness and decaying time constant of afternystagmus. Applied ergonomics, 63: 1-8.

Han, J., Bae, S. H, Suk, \& Hyeon-Jeong (2017). Comparison of Visual Discomfort and Visual Fatigue between Head-Mounted Display and Smartphone. Electronic Imaging, 2017(14): 212-217.

Hanslmayr, S., Gross, J., Klimesch, W., \& Shapiro, K. L. (2011). The role of $\alpha$ oscillations intemporal attention. Brain Res, 67: $331-343$.

Harricharan, S., Nicholson, A. A, Densmore, M., Théberge, J., Mckinnon, M. C, Neufeld, R. W, \& Lanius, R. A (2017). Sensory Overload and Imbalance: Resting-State Vestibular Connectivity in PTSD and its Dissociative Subtype. Neuropsychologia, [epub ahead of print].

Herrmann, C. S, Strüber, D., Helfrich, R. F, \& Engel, A. K (2016). EEG oscillations: From correlation to causality. International Journal of Psychophysiology, 103: $12-21$.

Hoyt, R. E, Lawson, B. D, Mcgee, H. A, Strompolis, M. L, \& Mcclellan, M. A (2009). Modafinil as a potential motion sickness countermeasure. Aviation, space, and environmental medicine, 80(8): 709-715.

Huster, R. J, Enriquez-Geppert, S., Lavallee, C. F, Falkenstein, M., \& Herrmann, C. S (2013). Electroencephalography of response inhibition tasks: functional networks and cognitive contributions, Int. J. Psychophysiol, 87: 217- 233.

Jensen, O., \& Mazaheri, A. (2010). Shaping functional architecture by oscillatory alpha activity: gating by inhibition. Front. Hum. Neurosci, 4 : 186.

Ji, J. T. T., So, R. H. Y., \& Cheung, R. T. F. (2016). Isolating the effects of vection and optokinetic nystagmus on optokinetic rotation-induced motion sickness. Human factors, 51(5): 739-751.

Kennedy, R. S, Drexler, J. M, Compton, D. E, Stanney, K. M, Lanham, D. S, \& Harm, D. L (2003). Configural Scoring of Simulator Sickness, Cybersickness and Space Adaptation Syndrome: Similarities and Differences. Virtual and Adaptive Environments? NTRS, $247:$ 1-23.

Kennedy, R. S, Lane, N. E, Berbaum, K. S, \& Lilienthal, M. G (1993). Simulator Sickness Questionnaire: an Enhanced Method for Quantifying Simulator Sickness. The International Journal of Aviation Psychology, 3(3): 203-220.

Kennedy, R. S., Lanham, D. S., Drexler, J. M., Massey, C. J., \& Lilienthal, M. G. (1997). A Comparison of Cybersickness Incidences, Symptom Profiles, Measurement Techniques, and Suggestions for Further Research. Presence: Teleoperators and Virtual Environments, 6(6): 638-644.

Keshavarz, B. et al. (2018). Comparing simulator sickness in younger and older adults during simulated driving under different multisensory conditions. Transportation research part F: traffic psychology and behaviour, 54: 47-62.

Keshavarz, B., \& Hecht, H. (2014). Pleasant music as a countermeasure against visually induced motion sickness. Applied ergonomics, $45(3)$ : 521-527.

Keshavarz, B., Riecke, B. E., Hettinger, L. J., \& Campos, J. L. (2015). Vection and Visually Induced Motion Sickness: How Are They Related?. Frontiers in Psychology, 6(472): 1-11.

Keshavarz, B., Stelzmann, D., Paillard, A., \& Hecht, H. (2015). Visually induced motion sickness can be alleviated by pleasant odors. Experimental brain research, 233(5): 1353-1364.

Kim, Y. Y., Kim, H. J., Kim, E. N., Ko, H. D., \& Kim, H. T. (2005). Characteristic Changes in the Physiological Components of Cybersickness. Psychophysiology, 42(5): 616-625.

Kiryu, T., \& So, R. H. Y. (2007). Sensation of presence and cybersickness in applications of virtual reality for advanced rehabilitation. J NeuroEngineering Rehabil, 4:34.

Knyazev, G. G. (2010). Antero-posterior EEG spectral power gradient as a correlate of extraversion and behavioral inhibition. The open neuroimaging journal, 4: 114. 
Koch, A., Cascorbi, I., Westhofen, M., Dafotakis, M., Klapa, S., \& Kuhtz-Buschbeck, J. P. (2018). The Neurophysiology and Treatment of Motion Sickness. Dtsch Arztebl Int, 115(41): 687-696.

Koslucher, F., Haaland, E., \& Stoffregen, T. A. (2016). Sex Differences in Visual Performance and Postural Sway Precede Sex Differences in Visually Induced Motion Sickness. Experimental brain research, 234(1): 313-322.

Lackner, J. R. (2014). Motion sickness: more than nausea and vomiting. Experimental brain research, 232(8): 2493-2510.

Lee, C., \& Jones, T. A (2017). Neuropharmacological Targets for Drug Action in Vestibular Sensory Pathways. Journal of Audiology \& Otology, 21 (3): 125.

Lee, Y. J, Lee, S., Chang, M., \& Kwak, H. W. (2015). Saccadic Movement Deficiencies in Adults with ADHD Tendencies. ADHD Attention Deficit and Hyperactivity Disorders, 7(4): 271-280.

Levac, D. E, Huber, M. E, \& Sternad, D. (2019). Learning and transfer of complex motor skills in virtual reality: a perspective review. J Neuroeng Rehabil, 16(1): 121 .

Leung, A. K, \& Hon, K. L. (2019). Motion sickness: an overview. Drugs Context, 8(2019): 9-4.

Litleskare, S., MacIntyre, T. E, \& Calogiuri, G. (2020). Enable, Reconnect and Augment: A New ERA of Virtual Nature Research and Application. Int J Environ Res Public Health, 17(5): 1738.

Liu, R., Peli, E., \& Hwang, A. D (2017). Measuring visually induced motion sickness using wearable devices. Electronic Imaging, 2017(14): 218-223.

Macefield, V. G, \& Walton, D. K (2015). Susceptibility to Motion Sickness Is Not Increased Following Spinal Cord Injury. Journal of Vestibular Research, 25(1): 35-39.

Maij, D. L, Van De Wetering, B. J, \& Franken, I. H (2017). Cognitive Control in Young Adults with Cannabis Use Disorder: an Event-Related Brain Potential Study. Journal of Psychopharmacology, 31(8): 1015-1026.

Malinska, M., Zuzewicz, K., Bugajska, J., \& Grabowski, A (2015). Heart Rate Variability (HRV) During Virtual Reality Immersion. International Journal of Occupational Safety and Ergonomics (JOSE), 21(1): 47-54.

Malińska, M et al. (2014). Subiektywne odczucia wskazujące na występowanie choroby symulatorowej i zmęczenie po ekspozycji na rzeczywistość wirtualną. Medycyna Pracy, 65(3): 361-371.

Meindertsma, T., Kloosterman, N. A, Nolte, G., Engel, A. K, \& Donner, TH (2017). Multiple Transient Signals in Human Visual Cortex Associated with an Elementary Decision. Journal of Neuroscience, 37(23): 5744-5757.

Meireles, A. E., Pereira, L. M. S., Oliveira, T. G, Christofoletti, G., \& Fonseca, AL (2010). Physiological Neurological Changes in Aging Affect the Balance Maintenance System. Rev Neurocienc, 18(1): 103-108.

Miyazaki, J. et al. (2015). Inter-hemispheric desynchronization of the human MT+ during visually induced motion sickness. Experimental brain research, 233(8): 2421-2431.

Morozetti, P. G., Ganança, C. F., \& Chiari, B. M. (2011). Comparison of Different Vestibular Rehabilitation Protocols in Patients with Peripheral Vestibular Dysfunctions. Soc Bras Fonoaudiol, 1(23): 44-50.

Munafo, J., Diedrick, M., \& Stoffregen, T. A. (2017). The Virtual Reality Head-Mounted Display Oculus Rift Induces Motion Sickness and Is Sexist in its Effects. Experimental Brain Research, 235(3): 889-901.

Munoz, D. P., Broughton, J. R., Goldring, J. E., \& Armstrong, I. T. (1998). Age-Related Performance of Human Subjects on Saccadic Eye Movement Tasks. Experimental Brain Research, 121(4): 391-400.

Naqvi, S. A. A., Badruddin, N., Jatoi, M. A, Malik, A. S., Hazabbah, W., \& Abdullah, B (2015). EEG Based Time and Frequency Dynamics Analysis of Visually Induced Motion Sickness (VIMS). Australasian Physical \& Engineering Sciences in Medicine, 38(4): 721-729.

Paillard, A. C., Quarck, G., Paolino, F., Denise, P., Paolino, M., Golding, J. F., \& Ghulyan-Bedikian, V (2013). Motion sickness susceptibility in healthy subjects and vestibular patients: effects of gender, age and trait-anxiety. $J$ Vestib Res, 23:203-209

Paolozza, A., Munoz, D. P., Brien, D., \& Reynolds, J. N. (2016). Immediate Neural Plasticity Involving Reaction Time in A Saccadic Eye Movement Task is Intact in Children with Fetal Alcohol Spectrum Disorder. Alcoholism: Clinical and Experimental. Research, 40(11): 2351-2358.

Park, J. R., Lim, D. W., Lee, S. Y., Lee, H. W., Choi, M. H., \& Chung, S. C. (2008). Long-Term Study of Simulator Sickness: Differences in EEG Response Due to Individual Sensitivity. International Journal of Neuroscience, 118(6): 857-865.

Pennel, I. M., \& Charron, C. Do (2015). Mental Workload and Presence Experienced when Driving a Real Car Predispose Drivers to Simulator Sickness? An Exploratory Study. Accident Analysis \& Prevention, 74: 192-202.

Petit, G., Kornreich, C., Noël, X., Verbanck, P., \& Campanella, S (2012). Alcohol-Related Context Modulates Performance of Social Drinkers in a Visual Go/No-Go Task: A Preliminary Assessment of Event-Related Potentials. PLoS One, 7(5): e37466.

Romero, A. C. L., Hayashi, M. S. Y., Kishi, M. S., Cardoso, A. C. V., \& Frizzo, A. C. F. (2015). Dizziness Handicap Inventory - Em um Grupo de Pacientes Submetidos a Reabilitação Vestibular Personalizada. Rev. CEFAC, 17(3): 792-800.

Schmal, F (2013). Neuronal Mechanisms and the Treatment of Motion Sickness. Pharmacology, 91(3-4): 229-241. 
Research, Society and Development, v. 10, n. 12. e29101220070, 2021

(CC BY 4.0) | ISSN 2525-3409 | DOI: http://dx.doi.org/10.33448/rsd-v10i12.20070

Sherman, C. R. (2002). Motion sickness: review of causes and preventive strategies. Journal of travel medicine, 9(5): 251-256.

Shupak, A., \& Gordon, C. R. (2006). Motion sickness: advances in pathogenesis, prediction, prevention, and treatment. Aviation, space, and environmental medicine, 77(12): 1213-1223.

Stoffregen, T. A., \& Riccio, G. E. (1991). An ecological critique of the sensory conflict theory of motion sickness. Ecol. Psychol, 3(3): 159-194.

Swann, NC (2013). et al. Intracranial electroencephalography reveals different temporal profiles for dorsal-and ventro-lateral prefrontal cortex in preparing to stop action. Cerebral Cortex, 23(10): 2479-2488.

Treleaven, J. et al. (2015). Simulator sickness incidence and susceptibility during neck motion-controlled virtual reality tasks. Virtual Reality, 19(3-4): 267-275.

Velasques, B., Bittencourt, J., Diniz, C., Teixeira, S., Basile, L. F, Salles, J. I., \& Nardi, A. E. (2013). Changes in saccadic eye movement (SEM) and quantitative EEG parameter in bipolar patients. Journal of affective disorders, 145(3): 378-385.

Velasques, B., Machado, S., Paes, F., Bittencourt, J., Domingues, CA, Basile, LF, \& Sack, AT (2011). Hemispheric Differences Over Frontal Theta-Band Power Discriminate Between Stimulus-Versus Memory-Driven Saccadic Eye Movement. Neuroscience letters, 504(3): 204-208.

Zhang, Z., Wang, Q., Liu, X., Song, P., \& Yang, B. (2017). Differences in Inhibitory Control Between Impulsive and Premeditated Aggression in Juvenile Inmates. Frontiers in Human Neuroscience, 11: 373.

Zhou, X., Qi, Xue-Lian, \& Constantinidis, C. (2016). Distinct roles of the prefrontal and posterior parietal cortices in response inhibition. Cell reports, 14(12): 2765-2773. 